Vol. 122006 pp. 243-250

\author{
Maciej Jędrusik \\ Institute of Developing Countries \\ E-mail: maciusik1@uw.edu.pl
}

\title{
ON THE EVOLUTION OF TROPICAL ISLANDS ECONOMIES IN MODERN TIMES
}

\begin{abstract}
Over several centuries the characteristic features of the economies of tropical islands were similar and unchanged. On almost all islands, independently of their genetic type, farming and fishing predominated, sprinkled with inter-island trade. With the European expansion, economies of the islands underwent transformations. The development of transportation and communication contributed to the increased accessibility of islands and to their inclusion into world economy. This phenomenon progressed particularly fast in the second half of the $20^{\text {th }}$ century, when already independent island states often searched for capital necessary for their sovereign existence. Numerous unconventional solutions were proposed, but it was tourism that achieved the greatest triumphs, gradually beginning to dominate in the economy of islands of almost all types.
\end{abstract}

Key words: Tropical islands, economy, tourism, economic transformation, Oceania.

Features of tropical island economy were changing, yet for the most of modern history economic activities on the islands were similar, which followed, in particular, from the island morphology related to their origins. Relatively similar climate in the zone between the tropics did not contribute to the differentiation of island economies. This was the situation both in the pre-colonial period and after the colonisation of the islands by economically developed countries. Gradually, on the islands of all oceans an economic transformation, at various times and rate, took place - from the traditional farming and fishing, to plantation farming, to tourism and New Economy.

\section{ECONOMIC SPECIALISATION OF ISLANDS IN THE PRE-COLONIAL AND COLONIAL PERIOD}

In the pre-colonial period traditional self-supporting farming was the main occupation of inhabitants of the islands, complemented by a limited exploitation of offshore waters - lagoons and the open sea. The need to possess "luxury" goods, exotic from the point of view of the islanders, was 
the basis for the development of inter-island trade, reaching large areas of the oceans.

One could surmise, with a large probability, that such model of economy: traditional farming, limited fishing and trade with neighbours, was common for almost all inhabited tropical islands on all oceans. This model was changing mostly under the influence of European colonisers, but at different historical moments, since every ocean became a region of European knowledge and conquest at different time.

Independently of the location of the island, farming was the most important branch of economy on the majority of tropical islands in the pre-colonial phase, when traditional farming was developing together with the accompanying fishing, and also in the early colonial phase, when the islands, predestined for such activities due to their natural environment conditions, became dominated by the plantation economy.

Gradually, trade - not only between the islands, but also between the colonies and the conquered lands - developed. Forest exploitation played a secondary, although at certain periods important $\left(17^{\text {th }}\right.$ and $18^{\text {th }}$ centuries on Atlantic islands, $19^{\text {th }}$ century on Pacific) role.

Some islands gained a dreary fame as prisons (e. g., Devil's Island) or penal settlement colonies (New Caledonia). Others - still less numerous - had an opportunity to develop thanks to the exploitation of raw minerals (e. g., Sal in the Cape Verde Islands, where salt had been mined since the $16^{\text {th }}$ century; Trinidad with its oil; Jamaica with its boxites; New Caledonia, with its nickel ore; on Vanuatu manganese ore is mined; on Viti Levu, gold).

\section{ECONOMIC TRANSFORMATION ACCOMPANYING THE DECOLONISATION PROCESS}

The $20^{\text {th }}$ century brought about a significant acceleration of the rate of economic transformations. This was a result of the weakening and the change of the form of political relations between the metropolis and the dependent territories, of the technological progress, as well as of globalisation, which gradually penetrated also the most remote and isolated territories. World wars and the post-war period of the Cold War effected a significant influence on this situation. It was then that the strategic importance of islands as platforms allowing for conquest, recovery or control of other territories (both insular and continental) and communication routes through the oceans was fully appreciated.

Strategic considerations and isolation made it possible to use certain tropical islands for experiments with modern military equipment. Relatively "innocent" installations, e. g., stations of satellite flight controls on Seychelles or Kiribati on the Christmas Islands (Kiritimati) were founded. After 1960 on the Atlantic island of Ascension an American observatory of space flights, later also of shuttles, was localised. Rocket control stations 
were created also on Grand Turk and on Bahamas (Grand Bahama, Eleuthera, San Salvador and Mayaguana).

Northern atolls of the Marshall Islands (Bikini, Rongelap, Enewetak, and Utrik) became the place where 67 American nuclear tests were performed. In 1955-57, nuclear tests were conducted on the uninhabited Johnston atoll. Until 1996, nuclear tests had been performed on Moruroa and Fangataufa atolls. On Kwajalein, surrounding the largest lagoon in the world, a large American military base had been located. Those actions destroyed the natural environment and sometimes the social one; but paradoxically, they were at the same time a source of significant profits of the island territories. This way new, also civil, technologies reached the islands, the military created infrastructure, employment for the local population; finally, metropolis did not spare money for transfer to the islands.

In $20^{\text {th }}$ century, the "quiet" world of the tropical islands approached the "restless" external world not only due to the strategic and military activities. The external world could reach islands thanks to the development of new forms of transportation and communication. The significance of the sea transportation decreased in favour of aeroplanes, which reached large distances faster. The development of international air transportation in the period between the two World Wars made many islands of Oceania a place of stopover in transpacific flights, and since the range of planes from that period was relatively small, many islands took advantage of this opportunity. Revolutionary changes took place also in communication. Submarine telecommunication cables appeared at the turn of the $20^{\text {th }}$ century. After 1910 , radio news reached most capitals of insular countries. Starting from 1970s, satellite communication has been developing. The simultaneous revolution in transportation and communication allowed the colonial metropolises to make decisions concerning localisation of such objects on remote islands whose existence transformed the existing social and economic structures (e. g., in French Polynesia: Centre d'Expérimentation du Pacifique). The deepest changes took place in plantation farming. Because of globalisation of world trade, the two most important plantation crops on tropical islands, sugar cane and coconut palm, brought smaller profits and the surface area of the plantation became to decrease. The process of decrease of the role of traditional and plantation farming in the second half of the $20^{\text {th }}$ century was characteristic for almost every tropical island. Agriculture receded before other, new ideas for a better economic future. Symptoms of "new agriculture" were only exceptions.

\section{MODERN ISLAND ECONOMIES}

Island countries and territories found themselves in a difficult situation, forced to make economic choices. Together with independence, new possibilities, related to the financial aid from abroad, appeared. The extent of this 
aid is non-negligible. On the world scale, small independent island countries receive nine times as much aid than other developing countries. Aid for overseas territories or for countries associated with economic super-powers is 32 as large as that for independent island countries ${ }^{1}$ (Crocombe, 2001). The aid is given even for the purpose of buying votes of a small country during voting in international organisations. Money transfers from abroad came also from emigrants. This phenomenon became so characteristic for islands that in 1980s economies of certain countries were referred to as $\operatorname{MIRAB}^{2}(\mathrm{Mi}=$ migrations, $\mathrm{R}=$ remittances, $\mathrm{A}=$ aid, $\mathrm{B}=$ bureaucracy) (Bertram, Watters, 1985 and 1986).

As a result of the progressing globalisation, ideas for the development of new, often illegal, branches of economy appeared. An interesting inventory of such ideas for island states on the Pacific was made by R. Crocombe (2001), although the phenomenon affects also other islands on other oceans. He lists:

- Sale o strategic rights (Federated States of Micronesia, Marshall and Palau Islands);

- Hiding of capitals of "rich and criminal" (Cook Islands, Nauru, Samoa, Vanuatu);

- Registration of "cheap flags" (Vanuatu and Marshall Islands);

- Warranty letters (Cook Islands, Vanuatu, Marshall Islands);

- Phone sex and data transfer (Tuvalu, Tonga, Niue, Solomon Islands and Vanuatu);

- "Dirty paradises": Sale of rights to submersion in waters of toxic waste and other waste harmful for the environment (Samoa, American Samoa, Tonga, Tuvalu, Solomon Islands, Vanuatu);

- Drug trafficking;

- Hazard games (Micronesia, Fiji, New Caledonia, Solomon Islands, Vanuatu, Cook islands);

- Sale of rights to use air space (Fiji, Nauru, Tonga);

- Sale of passports (citizenship) (Tonga, Marshall Islands, Kiribati);

- Sovereignty as tourist attraction (Cook Islands);

- Sale of sovereignty symbols (e. g., postal stamps and coins).

This extensive list can be extended even more. An important source of revenue of Fiji is its army, hired, for instance, for UNO missions. Island states admitted many atypical economic solutions also from other oceans. For instance, the Cape Verde Islands, Mauritius and Comoros earned money from co-operation with RPA, affected by ostracism in Africa, while weapons for rebels in Mozambique were transferred through Comoros.

Some islands were eager to admit new technologies. On Barbados, already in the early 1980 s, a few enterprises active in the duty-free zone dealt with electronic data processing and computer services.

1 This was pointed out also by G. Bertram (2003).

${ }^{2}$ Numerous emigrants, often more numerous than the entire population of the island, transfer money to native islands. The total amount of the transfers is comparable to the budgets of the territories; nonetheless, the bureaucracy absorbs almost all the money and foreign aid. 
Tax havens and offshore duty-free zones were created also on the Caribbean islands, a. o., on Bahamas, British Virgin Islands, Caiman Islands and Bermuda. A similar type of financial dealings was accepted on some Pacific islands.

New revenues made it possible to define and codify the notion of the exclusive economic zone. Thanks to that, some small, isolated island states control exclusive economic zones larger than some large states. Islands began receiving at their disposal vast areas of oceans increasing their sphere of influence by 100, 1000 and even 10000 times. For instance, the ratio of the land area to the economic zone area for the Cook Islands is 1:8000, for Nauru 1:15 000, for Tuvalu and Tokelau 1:30 000 and for Pitcairn 1:130 000 (Doumenge J.-P., 1984).

Together with the introduction of exclusive economic zones, fishing - a traditional occupation of the islanders - gained importance, although the sale of fishing licenses is nowadays more profitable. Traditional fishing has been complemented by the creation of aquacultures. Fish-farms - baits for tuna fishing - developed around the islands (e. g., on Guam), but also farms of fish for aquarists, farms of octopi (e. g., on Tarawa), and pearl-oyster farming is now the second, after tourism, source of profits of French Polynesia.

Mining loses its importance. Processing industry has developed only on few islands (not counting Hong Kong and Singapore, which are also tropical islands!). A commendable exception among islands is Mauritius. Industrial development was stimulated there by the creation of nine duty-free zones, the first of which was created in 1986. Mauritius cleverly took advantage of the fears of Hong Kong inhabitants about the take-over of the colony by the People Republic of China in 1997 and the flight of the Chinese capital. An important centre of processing industry is American Samoa, which since 1970 fulfils $10 \%$ of the American demand for canned fish, and the Netherlands Antilles, where oil refineries have been built on Curaçao and Aruba.

A change of the crop structure takes place in farming on islands. Together with globalisation, a fashion for exotic plants appeared, for instance, tropical plants, traditionally grown there and unknown to the "rest of the world", such as kava (Piper methysticum), noni (Morinda citrifolia), or exotic flowers. Among island territories there are also those that succeed to transform the traditional farming into a profitable export farming. Farmers on Pacific islands earn more from the sale of vanilla, copra, sugar, coffee, kava and other crops for export than for the local market. Nonetheless, on Hawaii, famous for its sugar cane and pineapple plantations, farming brings only $1.2 \%$ GNP and employs only $1.6 \%$ of the working force (Huetz de Lemps Ch., 2003).

\section{CONCLUSIONS - SEQUENCE OF CHANGES}

The scheme of changes in the structure of the economy of tropical islands, presented in Table 1, is of course a generalisation, even because nowadays 
on each ocean one can find examples of islands at different stages of economic transformation. It is also difficult to define the exact moments of the change of the predominating source of profits. For simplicity, mining - limited to only a few islands - and equally weakly spread processing industry have been omitted.

Table 1.

An outline of economic changes on tropical islands since the $15^{\text {th }}$ century

\begin{tabular}{|l|c|c|c|c|c|}
\hline \multirow{2}{*}{ Century } & \multicolumn{2}{|c|}{ Atlantic Ocean } & \multicolumn{2}{c|}{ Indian Ocean } & \multirow{2}{*}{$\begin{array}{c}\text { Pacific } \\
\text { Ocean }\end{array}$} \\
\cline { 2 - 6 } & West & East & $\begin{array}{c}\text { Mauritius, } \\
\text { Réunion, } \\
\text { Seychelles }\end{array}$ & Others & A F \\
\hline XV & A F & A F P & - & A F & A F F \\
\hline XVI & A F & P & - & A F & A F \\
\hline XVII & A F P & P & P & A F & A F \\
\hline XVIII & P & P & P & A F & A F \\
\hline XIX & P & P T & P & A F & A F P \\
\hline $1900-1950$ & P T & P T & P & P & P N \\
\hline $1960-1970$ & P T & P T & P & P & P T N \\
\hline $1970-1980$ & T N & P T & P T & P T & P T N \\
\hline $1980-1990$ & T N & P T & P T & P T & T N \\
\hline $1990-2000$ & T N & P T & P T & T & T N \\
\hline $2000-$ & T N & T & P T & T & T N \\
\hline
\end{tabular}

$\mathrm{A}$ - agriculture, $\mathrm{F}$ - fishing, $\mathrm{P}$ - plantations, $\mathrm{T}$ - tourism, $\mathrm{N}$ - new economy (MIRAB, offshore, tax „heaven”, etc.).

The analysis of the comparison brings the following conclusions:

1. Significant economic changes took place on islands on all oceans.

2. The smallest changes took place on the islands of the western Indian Ocean.

3. The earlier transformation began on the eastern (already in the $16^{\text {th }}$ century), and then on the western Atlantic (1 $7^{\text {th }} / 18^{\text {th }}$ century).

4. Everywhere (except for the Mascarene Islands and Seychelles) a sequence leading from the traditional farming and fishing, through plantation farming to tourism (dominating or coexisting with another branch of economy) can be seen.

5. The earliest to turn towards new economic ideas were Pacific territories.

6. New Economy is the most popular on western Atlantic and on Pacific; on the latter it appeared even before tourism.

7. Tourism is nowadays one of the most important branches of economy on islands on all oceans.

Worth noting are moments of disappearance or decrease in importance of the traditional farming (the earliest on eastern Atlantic, the latest in Oceania) and the tourism, ubiquitous at the end of the 20th century; first to 
appear on the eastern Atlantic (Canary Islands) and last on the Indian Ocean.

For a long time, islands have focused the imagination of potential travellers from the moderate zones and dreams about voyages were fuelled by skilfully conducted advertising campaigns of tourist agencies. Since the 1960 s tourism has become the most important source of foreign-currency profits for the majority of island states, gradually surpassing significantly profits from the sale of other goods and services. For instance, in 1983 in Antigua and Barbuda, profits from tourism constituted 14\% GNP (Dommen, Lebalé, 1987 , p. 215). In 1980 s the share of tourism in the GNP reached $50 \%$ on Bahamas, $33 \%$ on Seychelles and $10 \%$ on Barbados (Huetz de Lemps A., 1989, p. 10). In the early $21^{\text {st }}$ century, tourism industry on Guadeloupe brought $14 \%$ of GNP ( $10 \%$ on Martinique), gave employment to $10 \%$ of the working force, creating close to 20000 positions, of which 8000 directly in tourism (twice as much as on Reunion) (Nicolas, 2002, p. 225).

Authorities of almost all island states and territories glance at tourism as the potential source of welfare - even of those which are afraid of the influx of the "aliens", threatening to create deep transformations in the social space (e. g., Socotra, Maldives). Among the tropical islands one can notice a huge differentiation as regards the development and role of tourist industry in the economy. The differences are great both between the oceans (Caribbean Islands, "exploding" with tourism, vs. Melanesia, almost avoided by the tourists) and within each ocean. The individual islands and tourist regions differ also in the phases of the development of the tourist industry.

The scope and directions of tourist traffic to tropical islands also changes. In the early 1980 s, the most visited were the Caribbean Islands; Mauritius and Seychelles gained in importance; the Canary Islands were the traditionally important direction; while Pacific, except for Hawaii, was visited only by few tourists. And although this picture did not change overall in the early $21^{\text {st }}$ century, the disproportion between the individual areas decreased. Research conducted by J. L. McElroy resulted in the following conclusions: "47 islands were listed in the order from the most visited (St. Martin) to the least visited by tourists (Solomon Islands). In general, the upper half comprises the more traditional, developed and accessible Caribbean, Mediterranean and North-Pacific islands, while the lower half, more isolated, less visible and recently "emerged" islands of South Pacific and the Indian Ocean" (McElroy, 2002, p. 4).

The tourist industry seems thus the most important branch of economy on the tropical islands in the future.

\section{REFERENCES}

Bertram I. G., Watters R. F., 1985, The MIRAB economy in South Pacific microstates, Pacific Viewpoint, 26(3), 497-519. 
Bertra m I. G., Watters R. F., 1986, The MIRAB process: earlier analyses in context, Pacific Viewpoint, 27(1), 47-59.

Bertram G., 2003, On the Convergence of Small Island Economies with their Metropolitan Patrons, World Development, 32 (2), 343-364.

Crocombe R., 2001, The South Pacific, Suva, University of the South Pacific.

Dommen E., Lebalé N., 1987, Caractéristiques des exportations de services des pays insulaires, [in:] flles tropicales: insulairité, "insularisme", CRET, Université de Bordeaux, Bordeaux, 209.228.

D o u menge J.-P., 1984, Enjeu géopolitique et intérêt scientifique des espaces insulaires, [in:] Nature et homme dans les îles tropicales, Bordeaux, CEGET-CRET, 1-6.

Huetz de Lemps A., 1989, Le tourisme dans les petites îles tropicales et subtropicales, [in:] Iles et tourisme en milieux tropical et subtropical, CEGET-CRET, Talence, 1-12.

Huetz de Lemps A., 2003, Mutations spatiales et mutations sociales aux îles Hawaii, [in:] Guillaud D., Huetz de Lemps Ch., Sevin O. (eds.), 2003), Iles rêvées. Territoires et identités en crise dans le Pacifique insulaire, Paris, Presses de l'Université de Paris-Sorbonne, 221242.

McElroy J. L., 2002, The Impact of Tourism in Small Islands: a Global Comparison, Department of Business Administration and Economics, Notre Dame, Indiana (http:// egis.cefe.cnrs-mop.fr/Tourism\%20Frontpages/mcelroy\%20article.htm, modified on 28 November 2002).

$\mathrm{Nicol} \mathrm{as} \mathrm{T.,} \mathrm{2002,} \mathrm{Le} \mathrm{tourisme,} \mathrm{moteur} \mathrm{du} \mathrm{développement} \mathrm{de} \mathrm{la} \mathrm{Guadeloupe} \mathrm{au} \mathrm{XXIe} \mathrm{siècle?,}$ [in:] Burac M. (ed.), 2002, Les Antilles et la Guyane françaises à l'aube du XXI' siècle, Karthala, GEODE Caraïbe, Paris, 219-239.

English translation: Matgorzata Mikulska 